\title{
Pertumbuhan Batang Pada Beberapa Varietas Kedelai (Glycine max (L.) Merr) Terhadap Jenis Tanah Aluvial, Regosol Dan Latosol
}

\section{Stem Growth On Some Variety of Soybean (Glycine max (L.) Merr) Towards Type Of Aluvial, Regosol And Latosol Soil}

\author{
Kurniawan M.R.D ${ }^{1}$, P. S. Ajiningrum ${ }^{2}$ \\ ${ }^{1}$ Mahasiswa Prodi Biologi FMIPA Universitas PGRI Adi Buana Surabaya. \\ ${ }^{2}$ Staf Pengajar Prodi Biologi FMIPA Universitas PGRI Adi Buana Surabaya. \\ Email: $\underline{\text { dkurniawanreza@gmail.com }}$
}

\begin{abstract}
Abstrak
Penelitian ini bertujuan untuk mengetahui pertumbuhan 10 varietas kedelai unggul yang ditanam di 3 jenis tanah yang berbeda (aluvial, regosol dan latosol) dan untuk mengetahui apakah 3 jenis tanah tersebut memberikan pengaruh untuk pertumbuhan 10 varietas kedelai unggul dilihat dari 4 parameter (panjang hipokotil, panjang epikotil, panjang batang dan berat kering batang). Penelitian ini menggunakan Rancangan Acak Kelompok (RAK) yang terdiri dari 10 varietas tanaman kedelai unggul (anjasmoro, argomulyo, detam 1, detam 3 prida, detam 4 prida, detap 1, devon 1, devon 2, gepak kuning dan deja 1) dan 3 jenis tanah (aluvial, regosol, dan latosol) diulang sebanyak 2 kali. Data dianalisis menggunakan uji ANAVA 5\% dua jalur dan uji DMRT 5\%. Varietas kedelai unggul terbaik pada panjang hipokotil adalah Devon 2, pada panjang epikotil yaitu Anjasmoro, Devon 1 dan Devon 2, pada panjang batang dan berat kering batang yaitu Detap 1. Hasil uji DMRT menyatakan bahwa ketiga jenis tanah (aluvial, regosol dan latosol) memiliki pengaruh terhadap parameter panjang hipokotil dan panjang epikotil, sedangkan pada parameter panjang batang dan berat kering tanaman tidak memiliki pengaruh.
\end{abstract}

Kata Kunci: kedelai, varietas, uji daya tumbuh

\begin{abstract}
This study aims to determine the growth of 10 superior soybean varieties planted in 3 different types of soil (alluvial, regosol and latosol) and to find out whether the 3 types of soil give an effect to the growth of 10 superior soybean varieties viewed from 4 parameters (hypocotyl length, length epicotiles, stem length and stem dry weight).This study used a Randomized Block Design (RBD) consisting of 10 varieties of soybean plants (anjasmoro, argomulyo, detam 1, detam 3 prida, detam 4 prida, detap 1, devon 1, devon 2, yellow gepak and deja 1) and 3 types of soil (alluvial, regosol, and latosol) was repeated 2 times. Data were analyzed using the two-way ANAVA 5\% test and the 5\% DMRT test. The results showed a significant difference in soybean growth. The best soybean varieties in hypocotyl length are Devon 2, in epicotile length are Anjasmoro, Devon 1 and Devon 2, the stem length and dry weight of the stem are Detap 1. The DMRT test results state that all three soil types (alluvial, regosol and latosol) have influence on the parameters of hypocotyl length and epicotyl length, whereas the parameters of stem length and plant dry weight have no effect.
\end{abstract}

Keywords: Soybean, Variety, Growing test

PENDAHULUAN

Kementerian Pertanian menyatakan bahwa konsumsi kedelai di Indonesia mengalami peningkatan sebesar 1,93 persen per tahun, namun luas panen kedelai cenderung mengalami penurunan yang signifikan sebesar 3,28 persen per tahun (Kementan, 2015). Perlu adanya strategi dari pemerintah untuk mencapai produksi yang maksimal, salah satunya adalah dengan melakukan pemilihan jenis tanah yang sesuai dengan masing-masing varietas kedelai yang unggul.
Varietas unggul merupakan komponen teknologi yang paling cepat diadopsi oleh petani, karena mudah, murah dan kompatibel dengan teknologi lain. Pemilihan menggunakan varietas unggul berarti sebagian masalah produksi seperti kemasaman, kahat atau ketidakseimbangan hara, serta cekaman hama atau penyakit telah atau lebih mudah diatasi (Suhartina, 2005). Kedelai varietas unggul memiliki sifat kualitatif terhadap ketahanan pecah polong, toleran terhadap cekaman air dan tahan terhadap hama dan penyakit. Pada varietas 
anjasmoro, detap 1, detam 3 prida, dan deja 1 tahan terhadap pecah polong. Varietas unggul lain seperti varietas argomulyo, detam 1, detam 4 prida, devon 1 dan devon 2 juga tahan hama dan penyakit sedangkan pada gepak kuning agak tahan. Varietas unggul juga memiliki sifat kuantitatif yaitu keseragaman benih yang dihasilkan dan memenuhi standar mutu, sesuai pola tanam yang diterapkan petani (Nugrahaeni, 2019).

Upaya untuk peningkatan hasil produksi kedelai varietas unggul salah satunya yaitu perlu diadakan kajian mendalam mengenai varietas kedelai yang toleran terhadap pertumbuhan di tanah masam, tanah kering dan bentuk cekaman air, karena tanah merupakan media tumbuh bagi tanaman, sekaligus menjadi pensuplai unsur hara (Prabowo dan Subantoro, 2017). Kebutuhan unsur hara sangat diperlukan sebagai penunjang respon tumbuh tanaman kedelai, seperti nitrogen $(\mathrm{N})$, fosfor $(\mathrm{P})$, kalium $(\mathrm{K})$, kalsium $(\mathrm{Ca})$, dan magnesium (Mg) (Balitkabi, 2015).

Tanaman kedelai dapat tumbuh dengan baik pada berbagai jenis tanah dengan drainase dan aerasi tanah yang cukup baik. Jenis tanah yang cocok yaitu tanah Aluvial, Regosol, Grumosol, Latosol, dan Andosol (Suprapti, 2003 dalam Wijaya, 2015). Kedelai umumnya dibudidayakan di lahan sawah (irigasi dan tadah hujan), lahan kering (masam dan bukan masam), lahan pasang surut dan lahan rawa lebak.

Penelitian produktivitas beberapa varietas kedelai pada lahan kering sebelumnya pernah dilakukan oleh Anshori, dkk. (2019) yang menyatakan bahwa varietas tanah grumusol menghasilkan produktivitas kedelai tertinggi, diikuti tanah mediteran dan terendah adalah tanah latosol. Selain itu, penelitian yang dilakukan oleh Ikhwani (2017) menyebutkan bahwa varietas kedelai unggul anjasmoro yang ditanam di tanah latosol menunjukkan hasil yang lebih tinggi dan keragaan lebih baik pada tinggi tanaman, jumlah daun dan jumlah cabang tanaman setelah ditambahkan aplikasi isolat rhizobium.
Berdasarkan uraian diatas, penelitian ini bertujuan untuk mengetahui pertumbuhan 10 varietas kedelai unggul yang ditanam di 3 jenis tanah yang berbeda (aluvial, regosol dan latosol) dan untuk mengetahui apakah 3 jenis tanah tersebut memberikan pengaruh untuk pertumbuhan 10 varietas kedelai unggul dilihat dari 4 parameter (panjang hipokotil, panjang epikotil, panjang batang dan berat kering batang).

\section{METODE PENELITIAN}

Waktu dan Tempat

Penelitian ini dilakukan di Laboratorium Biologi dan Green House FMIPA Universitas PGRI Adi Buana Surabaya pada bulan Mei-Juni 2019.

\section{Bahan dan Alat}

Bahan yang digunakan dalam penelitian ini adalah tanah aluvial, regosol dan latosol, benih kacang kedelai varietas unggul (Anjasmoro, Argomulyo, Detam 1, Detam 3 Pride, Detam 4 Pride, Detap 1, Devon 1, Devon 2, Gepak Kuning, dan Deja 1) yang diproduksi oleh Unit Pengelolaan Benih (UPBS) yang berada di Jalan Raya Kendal Payak Km 8 Malang, Jawa Timur. Alat yang digunakan adalah bak plastik berukuran 60x80 cm, kawat jaring, kayu, paku, palu, penggaris, oven dan timbangan analitik.

\section{Rancangan Penelitian}

Rancangan penelitian ini mengunakan Rancangan Acak Kelompok (RAK) dengan menggunakan 3 kelompok perlakuan yaitu 3 jenis tanah (aluvial, regosol dan latosol) terhadap pertumbuhan 10 varietas unggul tanaman kacang kedelai (Anjasmoro, Argomulyo, Detam 1, Detam 3 Pride, Detam 4 Pride, Detap 1, Devon 1, Devon 2, Gepak Kuning, Dan Deja 1) dengan pengulangan masing-masing perlakuan sebanyak 2 kali. 


\section{Analisis Data}

Metode yang digunakan dalam penelitian ini yaitu Uji ANAVA dua jalur dengan taraf kepercayaan $95 \% \quad(\alpha$ 5\%). Apabila hasil analisis variasi menunjukan perbedaan antara perlakuan, maka dilakukan uji lanjut dengan menggunakan uji perbandingan DMRT pada taraf 5\% untuk mengetahui perlakuan paling baik.

\section{Prosedur Penelitian}

Prosedur penelitian ini meliputi, penggunaan wadah plastik berukuran $40 \times 32$ $\mathrm{cm}$. Masing-masing wadah telah berisi tanah aluvial, regosol dan latosol yang berfungsi sebagai media tumbuh tanaman. Selanjutnya benih ditanam pada kedalaman $1 \mathrm{~cm}$ dari atas permukaan tanah. Jarak tanam yang digunakan dalam penelitian ini adalah $4 \mathrm{~cm}$.
Pengamatan tanaman dilakukan saat berumur 10 hari setelah tanam (HST) untuk mengetahui daya tumbuh tanaman. pengamatan pertumbuhan batang meliputi: panjang hipokotil, panjang epikotil, tinggi tanaman dan berat kering batang pada tanaman.

\section{HASIL DAN PEMBAHASAN}

Benih 10 varietas kedelai unggul ditanam di tanah aluvial, tanah regosol dan tanah latosol. Tiga jenis tanah tersebut terlebih dahulu diujikan di Laboratorium Tanah, Badan Penelitian dan Pengembangan Pertanian, Malang. Parameter yang diujikan berdasarkan ketentuan dan persyaratan yang berlaku di laboratorium tersebut.

Tabel 1. Hasil Uji Tanah Aluvial, Regosol dan Latosol

\begin{tabular}{|c|c|c|c|c|c|}
\hline No. & Parameter Uji & Aluvial & Regosol & Latosol & Satuan \\
\hline 1. & Kadar Air & 4,12 & 2,81 & 18,86 & $\%$ \\
\hline \multirow[t]{2}{*}{2.} & $\mathrm{pH} \mathrm{H} \mathrm{H}_{2} \mathrm{O}$ & 8,3 & 6,6 & 5,8 & - \\
\hline & $\mathrm{pH} \mathrm{KCl}$ & 6,9 & 5,2 & 4,3 & - \\
\hline 3. & C-Organik & 0,89 & 0,61 & 0,16 & $\%$ \\
\hline 4. & Nitrogen Total & 0,10 & 0,09 & 0,04 & $\%$ \\
\hline 5. & $\mathrm{P}_{2} \mathrm{O}_{5}$ tersedia & 51 & 14 & 2 & ppm \\
\hline \multirow[t]{5}{*}{6.} & $\begin{array}{l}\text { Nilai Tukar } \\
\text { Kation dapat } \\
\text { ditukar }\end{array}$ & & & & \\
\hline & $-\mathrm{K}_{\mathrm{dd}}$ & 0,57 & 0,09 & 0,53 & me. $100 \mathrm{~g}^{-1}$ \\
\hline & $-\quad \mathrm{Ca}_{\mathrm{dd}}$ & 21,12 & 5,11 & 8,41 & me.100 g-1 \\
\hline & $-\quad \mathrm{Mg}_{\mathrm{dd}}$ & 2,24 & 0,62 & 1,52 & me. $100 \mathrm{~g}^{-1}$ \\
\hline & $-\quad \mathrm{Na}_{\mathrm{dd}}$ & 0,36 & 0,44 & 0,60 & me. $100 \mathrm{~g}^{-1}$ \\
\hline \multirow[t]{5}{*}{7.} & $\begin{array}{l}\text { Kapasitas } \\
\text { Tukar Kation }\end{array}$ & 21,59 & 7,72 & 20,34 & \\
\hline & - Pasir & 54 & 69 & 36 & $\%$ \\
\hline & - $\quad$ Debu & 22 & 14 & 27 & $\%$ \\
\hline & - $\quad$ Liat & 24 & 17 & 37 & $\%$ \\
\hline & Kriteria & $\begin{array}{l}\text { Lempung } \\
\text { liat } \\
\text { berpasir }\end{array}$ & $\begin{array}{l}\text { Lempung } \\
\text { berpasir }\end{array}$ & $\begin{array}{l}\text { Lempung } \\
\text { Berliat }\end{array}$ & \\
\hline
\end{tabular}

Laboratorium Tanah; Badan Penelitian dan Pengembangan Pertanian Malang

\section{Panjang Hipokotil}

Hasil penelitian menunjukkan bahwa jenis tanah dan varietas kedelai berpengaruh terhadap pertumbuhan panjang hipokotil pada tanaman kedelai $(\mathrm{P}<0,05)$. Untuk mengetahui varietas kedelai mana yang memberikan pengaruh, maka dilakukan uji
DMRT. Hasil uji DMRT dinyatakan bahwa ketiga jenis tanah (aluvial, regosol dan latosol) tidak memiliki perbedaan yang signifikan meskipun berdasarkan nilai ratarata menunjukkan jenis tanah aluvial lebih unggul dari yang lain. Hal ini dapat disebabkan karena kandungan hara pada 
tanah aluvial lebih tinggi daripada tanah regosol dan latosol (Tabel 1). Berdasarkan Gambar 1, pertumbuhan panjang hipokotil yang memiliki hasil terbaik adalah varietas Devon 2 pada tanah aluvial yaitu $14,7 \mathrm{~cm}$, Devon 2 dan Detap 1 pada tanah regosol $(12,7 \mathrm{~cm})$ dan Varietas Anjasmoro pada tanah latosol $(13,59 \mathrm{~cm})$. Hasil uji DMRT untuk varietas kedelai berdasarkan pengukuran panjang hipokotil menunjukkan varietas yang lebih unggul dibandingkan dengan varietas yang lain adalah Devon 2 dan Anjasmoro. Menurut Adie dan Krisnawati (2016), pada awal pertumbuhar pasting hipsis salah satunya dipengaruhi oleh jenis dan karakter varietas itu sendiri. Penelitian yang dilakukan oleh Sutopo dan Kuswantoro (2013) juga menyebutkan bahwa perbedaan pertumbuhan kecambah disebabkan oleh perbedaan varietas. Varietas seperti Devon 2 dan Anjasmoro menurut Jumakir dan Endrizal (2003), memiliki tingkat produksi tinggi, bijinya besar, polong tidak mudah pecah dan dapat beradaptasi pada lahan yang kering seperti latosol, sehingga menunjukkan hasil yang baik dalam pertumbuhan hipokotil dibandingkan dengan varietas yang lain.

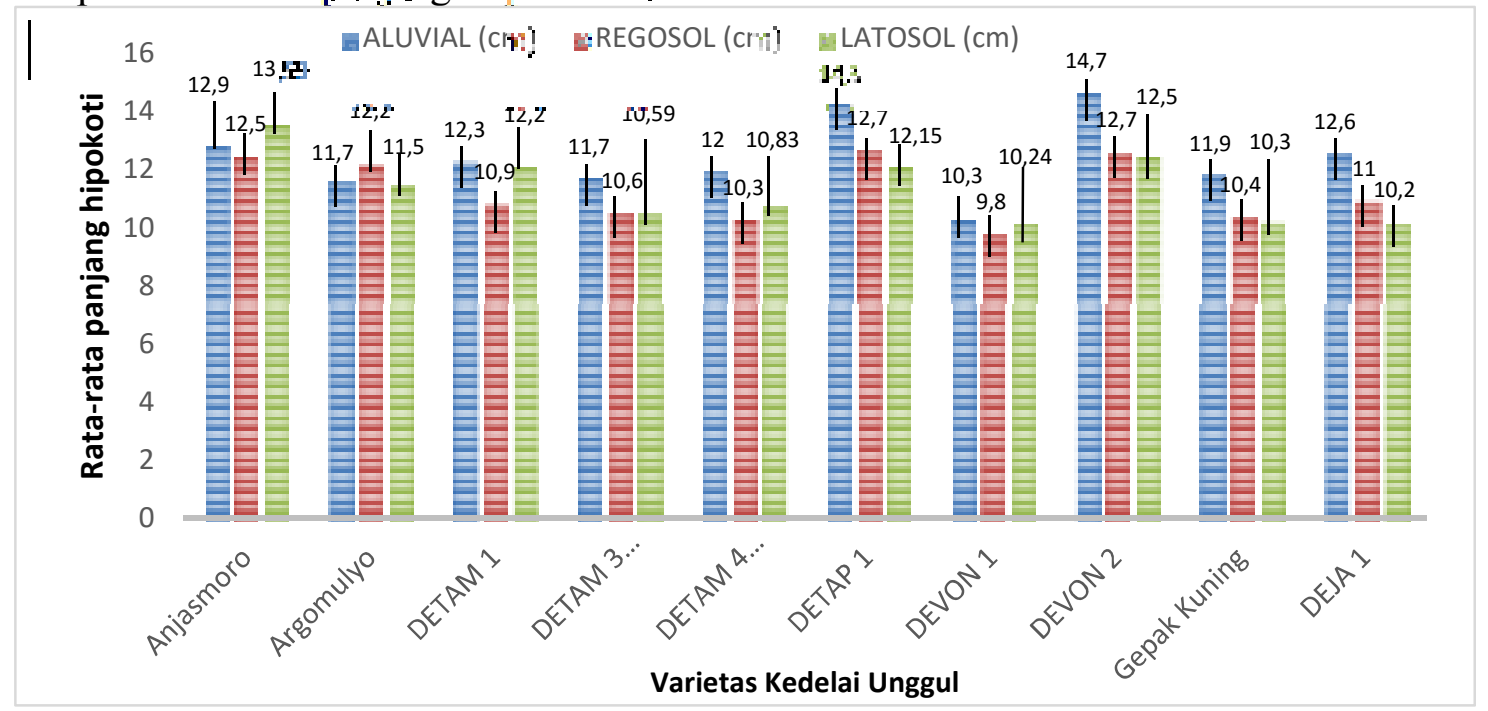

Gambar 1. Rata-rata panjang hipokotil 10 varietas kedelai unggul pada tanah aluvial, regosol dan latosol

\section{Panjang Epikotil}

Uji anova dilakukan untuk mengukur perbedaan jenis tanah dan untuk mengukur varietas 10 tanaman kedelai pada parameter panjang epikotil. Berdasarkan nilai sig. dari jenis tanah sebesar 0,008 dimana nilai tersebut kurang dari nilai alpha 0,05 sehingga dapat disimpulkan bahwa jenis tanah berpengaruh terhadap pertumbuhan panjang epikotil pada tanaman kedelai. Pengujian kedua yaitu 10 varietas kedelai yang diukur pada panjang epikotil didapatkan hasil bahwa dari nilai sig. dari jenis tanah sebesar $0,021<$ 0,05 (alpha), maka dapat disimpulkan bahwa varietas kedelai berpengaruh terhadap pertumbuhan panjang epikotil pada tanaman kedelai. Untuk mengetahui varietas kedelai mana yang memberikan pengaruh, maka dilakukan uji DMRT baik pada jenis tanah maupun varietas kedelai. Hasil uji DMRT untuk varietas kedelai berdasarkan pengukuran panjang epikotil pada tanaman kedelai, dapat disimpulkan bahwa 10 jenis varietas memberikan pengaruh yang sama terhadap pertumbuhan panjang epikotil. 


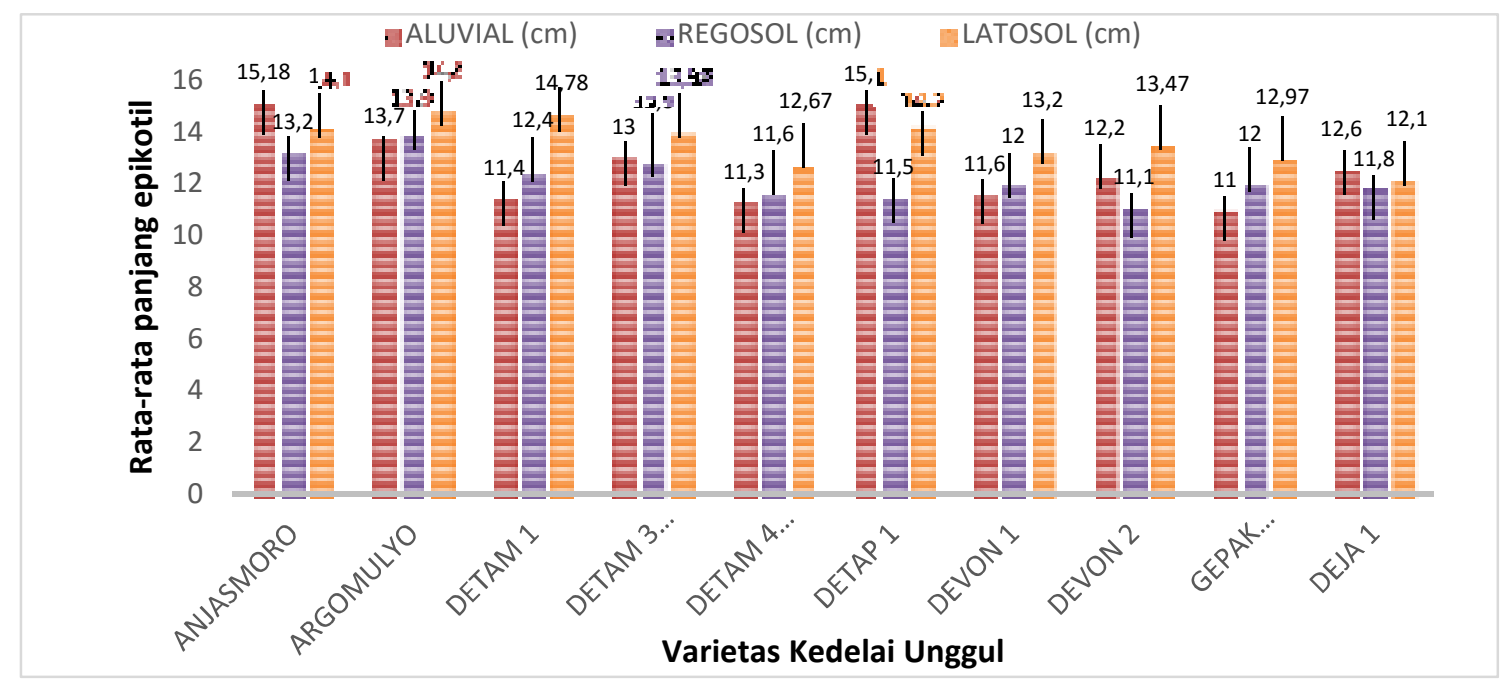

Gambar 2. Rata-rata panjang epikotil 10 varietas kedelai unggul pada tanah aluvial, regosol dan latosol

Gambar 2 menunjukkan bahwa tidak seluruhnya panjang epikotil kedelai yang tumbuh di tanah aluvial memberikan hasil yang baik. Pertumbuhan panjang epikotil yang menduduki nilai tertinggi pada Gambar 2 adalah Anjasmoro (15,18 cm) dan Detap 1 $(15,10 \mathrm{~cm})$ pada tanah aluvial. Jumlah ratarata panjang epikotil di tanah latosol lebih tinggi dibandingkan dengan aluvial dan regosol. Hal ini sesuai dengan uji DMRT, yaitu bahwa dari ketiga jenis tanah (aluvial, regosol dan latosol), jenis tanah latosol memberikan dampak yang lebih baik pada panjang epikotil dibanding dengan jenis tanah lainnya. Hal ini bisa jadi disebabkan karena struktur tanah latosol yang memiliki

\section{Panjang Batang}

Berdasarkan uji ANAVA yang dilakukan untuk mengukur perbedaan jenis tanah dan untuk mengukur varietas 10 tanaman kedelai pada parameter panjang batang tanaman, nilai sig. dari jenis tanah sebesar 0,108 dimana nilai tersebut lebih dari nilai alpha 0,05 , sehingga dapat disimpulkan bahwa jenis tanah tidak berpengaruh terhadap pertumbuhan panjang batang pada tanaman kedelai. Pengujian kedua yaitu 10 varietas kedelai yang diukur pada panjang batang didapatkan hasil bahwa varietas kedelai diketahui nilainya sebesar 0,000 . Nilai tersebut kurang dari nilai alpha $(0,05)$, artinya bahwa perbedaan varietas kedelai kadar air lebih tinggi daripada aluvial dan regosol (Tabel 1). Menurut Nugraha dkk. (2013) dan Ai dan Ballo (2010) air merupakan salah satu faktor luar yang sangat penting dalam pertumbuhan kedelai, karena penyerapan air merupakan tahap awal perkecambahan biii. Tanah bertekstur liat seperti latosol, memiliki ruang pori halus yang lebih banyak, sehingga kemampuan menahan air didalam tanah lebih banyak dibandingkan tanah bertekstur kasar atau bertekstur pasir (regosol) yang memiliki ruang pori halus lebih sedikit, sehingga kemampuan menahan air juga lebih sedikit (Madjid, 2009).

memberikan pengaruh terhadap pertumbuhan panjang batang. Hasil uji DMRT untuk varietas kedelai berdasarkan pengukuran panjang batang pada tanaman kedelai, dapat disimpulkan bahwa varietas Detap 1 lebih unggul dibandingkan dengan varietas lainnya. Menurut Balitkabi (2018), Detap 1 memiliki ketahanan lebih baik daripada varietas lain terhadap tanah dengan status nutrisi yang rendah dan kandungan bahan organik sedikit. Selain itu, Detap 1 termasuk dalam kelompok berbiji besar yang tahan rebahan dan pecah polong serta ukuran biji setara dengan Anjasmoro tetapi umur masaknya lebih genjah dibandingkan dengan 
Anjasmoro. Hal tersebut menguntungkan

bagi petani khususnya pada hasil produksi.

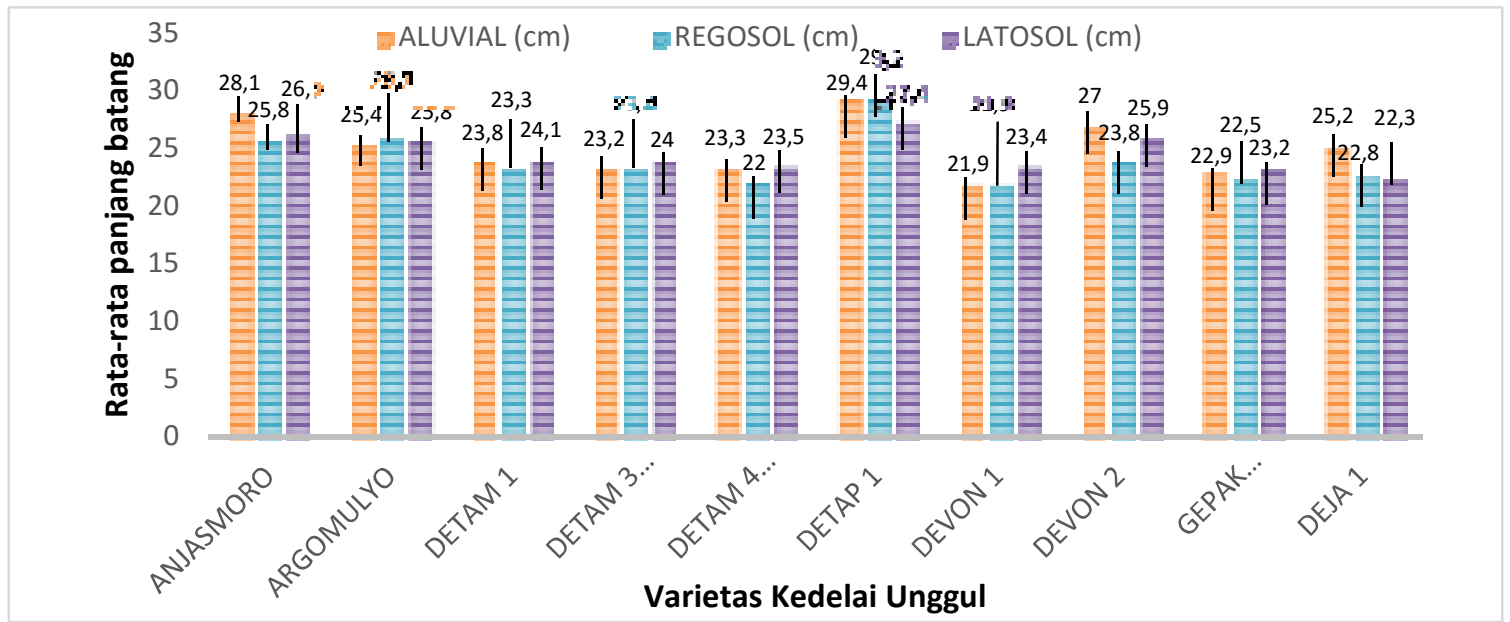

Gambar 3. Rata-rata panjang batang tanaman 10 varietas kedelai unggul pada tanah aluvial, regosol dan latosol

Gambar 3 menunjukkan bahwa hasil terbaik pada pertumbuhan batang adalah varietas Detap 1 pada tanah aluvial yaitu 29,4 $\mathrm{cm}$. Tanah aluvial dalam penelitian ini menunjukkan hasil yang baik pada pertumbuhan batang karena berdasarkan hasil uji tanah pada tabel 1 , tanah aluvial yang digunakan dalam penelitian ini memiliki kadar nitrogen total lebih tinggi yaitu sebesar $0,10 \%$ daripada tanah regosol $(0,09 \%)$ dan tanah latosol $(0,04 \%)$.

Lakitan (2000) dalam Haryadi dkk. (2015) menyatakan bahwa pertambahan panjang tanaman merupakan proses fisiologi dimana sel melakukan pembelahan dan proses pembelahan tanaman memerlukan unsur hara esensial dalam jumlah cukup diserap tanaman melalui akar. Lingga (2001) dalam Haryadi dkk. (2015) menyatakan bahwa nitrogen dalam jumlah cukup berperan untuk mempercepat pertumbuhan tanaman secara keseluruhan, khususnya batang dan daun, dan kadar nitrogen yang cukup yang ada di tanah aluvial berperan dalam pembentukan sel, jaringan, dan organ tanaman.

\section{Berat Kering Batang}

Hasil pengujian jenis tanah dan varietas kedelai diketahui berpengaruh terhadap berat kering batang. Untuk mengetahui jenis tanah dan varietas mana yang lebih baik maka dilakukan uji DMRT. Hasil uji DMRT jenis tanah menunjukkan bahwa ketiga jenis tanah tidak memiliki pengaruh yang berbeda. Ketiga jenis tanah tersebut akan menghasilkan pertumbuhan berat kering batang yang sama, sedangkan untuk varietas kedelai menunjukkan bahwa varietas yang unggul untuk berat kering batang adalah varietas Detap 1. 


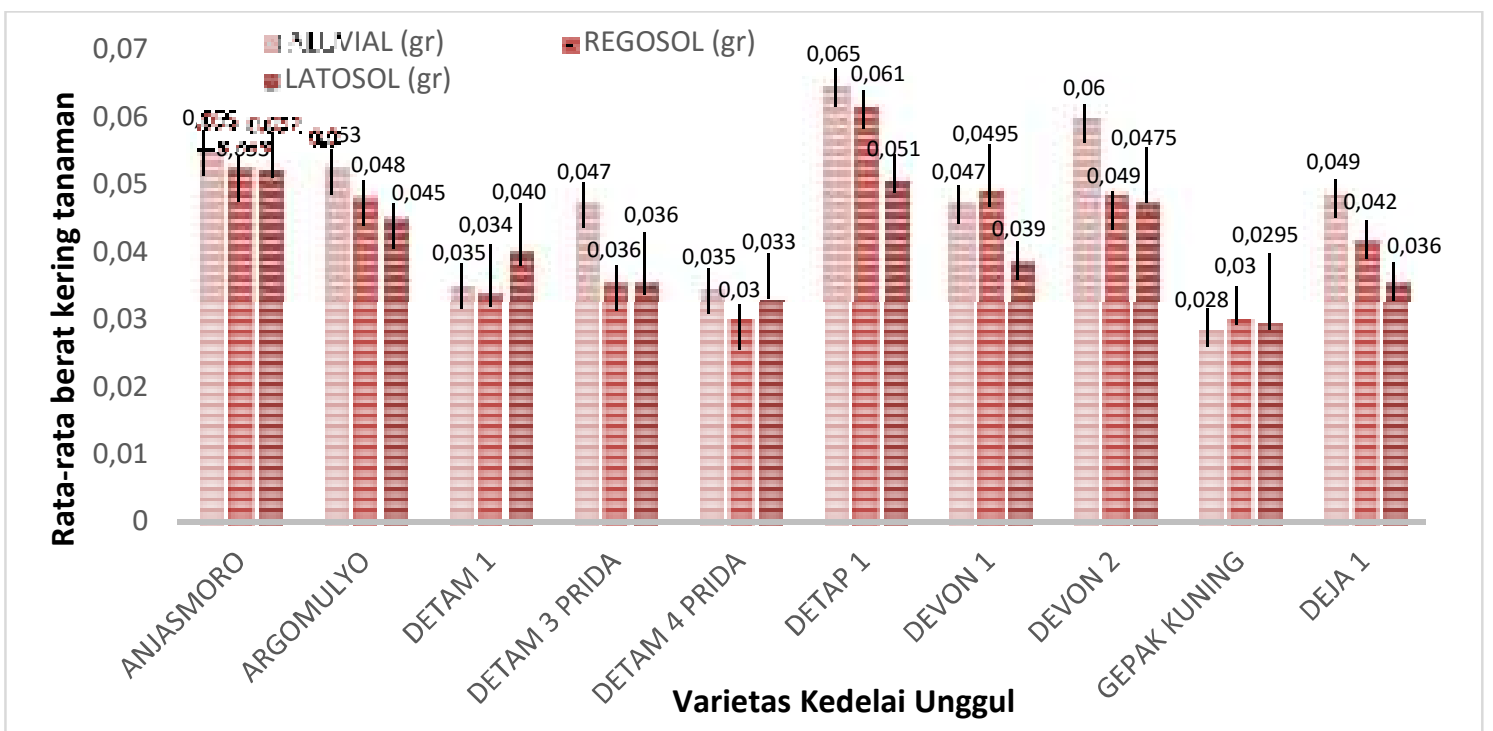

Gambar 4. Rata-rata panjang batang tanaman 10 varietas kedelai unggul pada tanah aluvial, regosol dan latosol

Berdasarkan Gambar 4, parameter berat kering batang yang paling baik ditunjukkan pada varietas Detap 1 pada tanah aluvial yaitu 0,065 gr. Berat kering tanaman merupakan hasil bersih asimilasi $\mathrm{CO}_{2}$ dari hasil penimbunan yang dilakukan selama tumbuh dan berkembangnya suatu tanaman dan pengukuran bobot kering merupakan tolok ukur yang lebih kuantitatif dan obyektif dan bobot kering menggambarkan kemampuan benih dalam memanfaatkan cadangan makanan untuk tumbuh menjadi kecambah normal (Shari dkk. 2013, Ardiansyah, 2017).

Selain itu, kandungan kadar C-organik, Nitrogen total dan Kapasitas Tukar Kation (KTK) dalam tanah aluvial di penelitian ini lebih tinggi daripada tanah regosol dan tanah latosol (Tabel 1), sehingga varietas Detap 1 mampu tumbuh lebih baik di tanah aluvial dibandingkan varietas Detap 1 yang tumbuh di regosol maupun latosol. Kandungan Corganik yang rendah pada tanah regosol dan latosol menunjukkan rendahnya produksi bahan organik yang merupakan salah satu parameter yang menentukan kesuburan tanah (Prabowo dan Subantoro, 2017). Selain itu, KTK juga merupakan sifat kimia tanah yang sangat erat hubungannya dengan kesuburan tanah sehingga tanah dengan nilai KTK rendah tidak mampu menyerap dan menyediakan unsur hara yang baik untuk tanaman (Roni, 2015).

Selama ini, varietas mempunyai peranan penting dalam perkembangan kedelai karena untuk meningkatkan produktivitas kedelai yang tinggi ditentukan oleh potensi daya hasil dari varietas unggul yang ditanam. Potensi hasil biji kedelai di lapangan masih dipengaruhi oleh hubungan antara faktor genetik varietas dengan pengelolaan kondisi lingkungan dimana kedelai tersebut tumbuh. Bila lingkungan tumbuh tidak dikelola dengan baik, potensi daya hasil biji yang tinggi dari varietas unggul tersebut tidak dapat tercapai (Wahdina, 2004).

\section{KESIMPULAN}

Varietas kedelai unggul terbaik pada panjang hipokotil adalah Devon 2, pada panjang epikotil yaitu Anjasmoro, Devon 1 dan Devon 2, pada panjang batang dan berat kering batang yaitu Detap 1. Hasil uji DMRT menyatakan bahwa ketiga jenis tanah (aluvial, regosol dan latosol) memiliki pengaruh terhadap parameter panjang hipokotil dan panjang epikotil, sedangkan pada parameter panjang batang dan berat kering tanaman tidak memiliki pengaruh. 


\section{SARAN}

Perlu dilakukan penelitian lebih lanjut mengenai karakter morfofisiologi pada varietas kedelai unggul yang adaptif pada lahan kurang nutrisi sehingga dapat dijadikan sebagai acuan seleksi pada proses pemuliaan tanaman.

\section{UCAPAN TERIMA KASIH}

Terima kasih kepada para Dosen Biologi FMIPA UNIPA Surabaya atas kritik dan sarannya dalam menyelesaikan penelitian ini. Terima kasih juga disampaikan penulis kepada rekan-rekan mahasiswa yang telah memberikan dukungan kepada penulis.

\section{DAFTAR PUSTAKA}

Adie, M.M dan A. Krisnawati. 2016. Biologi Tanaman Kedelai. http://balitkabi.litbang.pertanian.go.id/w pcontent/uploads/2016/03/dele_3.muchl ish-1.pdf, diakses 20 April 2020.

Anshori, A., E. Srihartanto dan D. Riyanto. 2019.Produktivitas Beberapa Varietas Kedelai Pada Lahan Kering di Kab. Gunung Kidul D.I. Yogyakarta. Research Fair Unisri. Vol 3(1): 463-467.

Ardiansyah. 2017. Aplikasi Kombinasi Limbah Cair Industri Tempe dan Urea Pada Pertumbuhan dan Hasil Selada (Lactuca sativa). Skripsi. Universitas Muhamadiyah Yogyakarta. D.I. Yogyakarta.

Haryadi, D, H. Yetti, dan S. Yoseva. 2015. Pengaruh Pemberian Beberapa Jenis Pupuk Terhadap pertumbuhan dan Produksi Tanaman Kailan (Brassica alboglabra L.). Jom Faperta. Vol 2(2).

Ikhwani. 2017. Cara Aplikasi Isolat Rhizobium dan Pengaruhnya pada VUB Kedelai di Tanah Latosol. Prosiding Seminar Hasil Penelitian Tanaman Aneka Kacang dan Umbi: 153-164.

Jumakir dan Endrizal. 2014. Produktivitas Kedelai Varietas Anjasmoro Pada Kondisi Cekaman Kekeringan Di Provinsi Jambi. Prosiding Seminar Hasil Penelitian Tanaman Aneka Kacang dan Umbi: 282-287.
Kementrian Pertanian Republik Indonesia. 2015. Rencana Strategi Kementerian Pertanian Tahun 2015-2019. Jakarta: Biro Perencanaan.

Lakitan. 2011. Dasar-Dasar Fisiologi Tumbuhan. Raja Grafindo Persada. Jakarta

Larcher, W. 1975. Physiological Plant Ecology: Ecophysiology and Stress Physiology of Functional Groups. Third Edition. Springer. New York.

Lingga dan Marsono. 2003. Petunjuk Penggunaan Pupuk. Penebar Swadaya. Jakarta

Madjid, A. 2009. Fisika Tanah. http://dasar2ilmutanah.blogspot.com/20 09/04/fisika-tanah-bagian-6-air-tanahdan.html, diakses 17 Mei 2019.

Nugraha, Y.S., T. Sumarni dan R. Sulistyono. 2014. Pengaruh Interval Waktu dan Tingkat Pemberian Air Terhadap Pertumbuhan dan Hasil Tanaman Kedelai (Glycine max (L) Merril.). Jurnal Produksi Tanaman, Vol 2(7):552559.

Nugrahaeni, N. 2007. Modul-C: Varietas dan Teknologi Produksi Benih Kedelai. Balai Penelitian Tanaman Kacang-kacangan dan Umbi-umbian. Malang.

Prabowo, R., dan Subantoro, R. 2017. Analisis Tanah Sebagai Indikator Tingkat Kesuburan Lahan Budidaya Pertanian di Kota Semarang. Cendekia Eksakta, Vol 2(2): 59-64.

Roni, N.G.K. 2015. Bahan Ajar: Tanah Sebagai Media Tumbuh. Universitas Udayana.

Sadjad, S. 1993. Dari Benih Kepada Benih. Jakarta: Gramedia.

Shari, P., Y. Nurmiaty, dan N. Nurmauli. 2013. Pengujian Vigor Benih Kedelai Varietas Grobogan Hasil Pemupukan NPK Majemuk Pada Umur Simpan Dua Bulan. Jurnal Agrotek Tropika, Vol 1(2): 183-188.

Suhartina. 2005. Deskripsi varietas Unggul Kacang-kacang dan Umbi-umbian. Balai Penelitian Tanaman Kacang-kacangan dan Umbi-umbian. Malang. 
Suprapti, M.L. 2003. Pembuatan Tempe. Penerbit Kanisius. Yogyakarta.

Wahdina, 2004. Evaluasi Kemajuan Seleksi Generasi F3 dan F4 Persilangan Kedelai
Varietas Selamat X GH-09. Tesis. Institut Pertanian Bogor.Bogor. 